This is a self-archived version of an original article. This version may differ from the original in pagination and typographic details.

Author(s): Alava, Henni

Title: The everyday and spectacle of subdued citizenship in northern Uganda

Year: 2020

Version: Accepted version (Final draft)

Copyright: (c) 2020 Taylor \& Francis

Rights: In Copyright

Rights url: http://rightsstatements.org/page/InC/1.0/?language=en

Please cite the original version:

Alava, H. (2020). The everyday and spectacle of subdued citizenship in northern Uganda. In K. Holma, \& T. Kontinen (Eds.), Practices of Citizenship in East Africa : Perspectives from Philosophical Pragmatism (pp. 90-104). Routledge. Routledge Explorations in Development Studies. https://doi.org/10.4324/9780429279171-7 


\title{
7 The everyday and spectacle of subdued citizenship in northern Uganda
}

\author{
Henni Alava
}

\section{Introduction}

How does it feel to be a citizen? This chapter draws attention to the observation that every citizen is a body which exists in the world in a particular place and time. In this vein, it builds on the contention that citizenship is not just a static status, but something that is done - actively or passively, consciously or unconsciously, willingly or reluctantly - but always by a body. Understanding how citizenship feels and has historically felt is thus a crucial aspect of understanding citizenship in any given context. Drawing on ethnographic research in the Acholi region of northern Uganda, I demonstrate how citizenship practices are embedded in particular relationships between the state and its citizens. Employing aspects of Achille Mbembe's theory of postcolonial statehood, the chapter highlights the role of everyday violence and spectacular political performances in citizenship practices in contemporary Uganda.

From 1986, when the rebel forces of the incumbent president, Yoweri Museveni, took over Kampala, until 2006, the Acholi region was ravaged by warfare between the Lord's Resistance Movement/Army (LRM/A) rebels and the Ugandan state. During the latter years of the northern Ugandan war, and in the few years of intense post-war reconstruction that followed, the Acholi region was the target of massive humanitarian and development intervention. Much of this intervention espoused, at least on paper, a "rights-based" approach, and has included so-called "civic education" activities. The rhetoric and jargon of active citizenship, democracy, human rights, participation, empowerment and so on, are thus well-known in the region, both to the former participants and even more so to the former employees of such projects. As I show, however, there is a disheartening gap between the benign rhetoric and the malign practice of state-citizen relations in Uganda. Decades of violent encounters with the state, and experiences of not being protected by the state, have led many of the Acholi people living in this region to embody what I refer to as subdued citizenship. In contrast to the informed, active and engaged citizens envisioned by theories of "good citizenship", subdued citizens engage in the body politic on the basis of uncertainty and misinformation and relate to the state primarily through submission or aversion. 
My analysis draws from altogether ten months of ethnographic fieldwork that I conducted primarily in Kitgum town, between the years 2012 and 2016. The analysis that I unfold in this chapter draws from over a hundred formal interviews, media and other secondary sources, and detailed ethnographic fieldnotes of religious and political events and formal and informal gatherings. The focus of the research project was on the role of the Catholic and Protestant (Anglican) Church in the re-imagining of society and politics in the aftermath of war (Alava 2017b). In this chapter, I elaborate on arguments I have developed in greater empirical detail elsewhere (see ibid.), with a particular eye to the question of citizenship.

After outlining a theoretical approach to the chapter's analysis, I sketch an overview of the recent history of state-citizen relations in northern Uganda. Thereafter, I turn to ethnographic evidence to argue that the everyday in the Acholi region is tinged by silence and fear pertaining both to the violence of the past and to the uncertainty and fears of violence in the present. The spectacular moments of state performance that take place, and that are interpreted in the midst of this everyday, include presidential visits to church celebrations, one of which I use to illustrate my argument. I conclude by returning to reflect on the question of how and where citizenship is learned and consider the prospects for growth into citizenship in a context profoundly imbued with violence.

\section{Citizenship and state violence}

Grasping what citizenship means in northern Uganda - and arguably, in all former colonies - requires the recognition of violence as one of the constitutive elements of the relationship between states and citizens. As a lineage of scholars since Fanon (1967) has argued, this violence has its roots in the violence of colonialism, which left its marks not only on the structures and trappings of the state, but in the minds and bodies of its citizens. Writing of China, Kleinman and Kleinman observe:

Bodies transformed by political processes not only represent those processes, they experience them as the lived memory of transformed worlds. The experience is of memory processes sedimented in gait, posture, movement, and all the other corporal components which together realize cultural code and social dynamics in everyday practices.

$(1994,716-717)$

For Achille Mbembe, the relationship between rulers and subjects (dubbed states and citizens in independence constitutions) - is "inscribed in a largely shared symbolic order" (Mbembe 2006, 159). Violence and destruction, alongside possession and enjoyment, are foundational for this order. Yet because the symbolic order is shared, violence and destruction need not simply be impressed upon subjects by their rulers: the subjects of power 
themselves participate in creating and upholding the regime to which they are subjected. In Judith Butler's rephrasing: "power compels its subjects ritualistically to perform, within and through the mundane practices of civil society, a ratification of its own spectacular excess" (Butler 1992, 68).

Yet in Mbembe's analysis there is a double nature to the events and practices whereby citizens ratify the state - a duality through which the overwhelming power of the state may at times be called to question:

This very process of ratification becomes itself the site for a subtle delegitimation of state power. The paradox is that this subtle process takes place through the very authorizing or ratifying rituals... [T] his kind of deauthorizing subversion which takes place in and through the exercise of ratification re-authorizes that power at the same time that it exposes its vulnerability.

(Mbembe 2006, 161)

Although Mbembe acknowledges the potential for citizens to destabilize the violent excess of state power through their participation, the overall tone of his analysis remains bleak. One among the critics to point this out is Mikael Karlström, who, drawing from ethnographic research of political ceremonies in Buganda, argues that whereas Mbembe depicts the ceremonial patterns of power as intrinsically pathological, Karlström's own analysis suggests that these ceremonies may in fact provide "resources for popular critical consciousness" (2003). In part, these different interpretations are dependent on the regionally and temporally specific relationships between the state and its citizens. In some places more than others, the state forces citizens into submission to the degree that little or no space for critical consciousness remains.

\section{Legacies of state violence in northern Uganda}

The northern Ugandan war is commonly portrayed as a "rebel war by the Lord's Resistance Army", or as an internal conflict between the LRA and the Ugandan government. However, over the years, the war became deeply embroiled in relations of power and money that far exceeded the local arena: proxy warfare between Sudan and Uganda (Prunier 2004); the plunder and global trade of natural resources (Zeller 2013); attempts to protect Uganda's role as a "golden boy" of the international aid regime (Mwenda 2010); the US-led "war against terror" (Branch 2012); the selfdefeating practices of humanitarian assistance (Finnström 2012); and battles waged in the field of international criminal justice (Branch 2007). Amidst such global "shadows of war" (Nordstrom 2004), Acholi citizens had very little scope for influencing the trajectories of their lives - something of which they were painfully aware (Finnström 2006). Central to this sense of abjection was the fact that civilians suffered at the hands of both 
the LRM/A rebels and the Ugandan army - often on account of one party's suspicion that civilians were supporting the other.

The Lord's Resistance Army and its predecessors launched their rebellion in 1986, as a response to violence meted out against the Acholi people in the wake of the capture of state power by incumbent president Yoweri Museveni (see, for instance, Atkinson 2010; Finnström 2009). Whereas in many other parts of the country Museveni was hailed as a saviour who ended the violent chaos of the preceding decades; for the Acholi, who had previously held prominent positions in the government and army, there was much to fear in Museveni's ascent to power. The profound distrust felt by many Acholi towards Museveni's regime deepened during the northern Ugandan war. Not only did the state force people into internal displacement in squalid conditions, many for a whole two decades, the military also meted out harsh violence against civilians. Museveni was also accused of deliberately perpetuating the war because it was so enormously profitable for a small military elite, and in order to justify military expenditure to the country's international donors. The outcomes of the war for Acholi citizens were terrifying.

Chris Dolan has described the situation of Acholi citizens during the war as one of social torture. What distinguishes social torture from individual torture is that it takes place over long periods of time across a vast geographic area and takes the form of violence, intimidation, sexual abuse (see also Porter 2016) and humiliation that targets an entire community or society. Social torture is perpetrated by multiple actors and is justified to a broader society through the application of tailored public discourses (Dolan 2009, 12). Dolan argues that the northern Ugandan war was particularly traumatising for many Acholi because the very entity that was supposedly responsible for protecting its citizens - the state - was itself culpable for much of their suffering.

The war was an outgrowth of a long history of violence in the region. The Acholi suffered tremendously under Idi Amin's reign, and British colonization in this region was brutally violent, as were the slave and cattle raids that preceded it. Yet the overwhelming majority of the Acholi population is too young to have personal memories of the time before Museveni; it is thus primarily against the backdrop of the National Resistance Movement (NRM) regime that relationships between the state and its citizens are crafted in northern Uganda. Of note is that my latest visit to northern Uganda in 2016, from which the second of my ethnographic examples below draws, coincided with a presidential election. As during earlier elections, this was a time of heightened political awareness, rumours, and fear; my analysis is thereby particularly tuned in to aspects of the "sense of citizenship" that, had I conducted my fieldwork in less strained times, may have gained less prominence. Yet I argue that the points I make have more general validity. For instance, the heightening of Museveni's anti-opposition measures in recent years bears witness to the relevance of my analysis for a general understanding of citizenship in Uganda. 


\section{Learning citizenship in the everyday: Memories, rumours, fear}

In February 2015, Kitgum town was busy preparing for the arrival of President Yoweri Museveni as the guest of honour at two different church events: the centenary celebration of Kitgum Catholic Mission, and the national commemoration of Saint Janani Luwum, an Anglican bishop killed by Idi Amin for his opposition to the violence of Amin's regime. In the midst of preparations, a rumour circulated in town that "some people" some claimed them to be "men from [the capital city] Kampala" - had been inciting people to insurgency in a remote village in Eastern Acholi. As the rumour had it, numerous army trucks had appeared, and people had been forced to burn their own huts and the surrounding bush so that the soldiers could search for weapons allegedly hidden by the purported rebels. There was no reference to such events in the national media, and the various people who mentioned the rumour to me all insisted it had come to them through acquaintances with relatives or friends living in the affected area. The details in the story were somewhat vague, which was not surprising. As one man put it when I asked him for more details, "Here, it is hard to know what is actually happening."

While there was no way for me to verify whether the rumour was grounded in fact, what is noteworthy is that the villains of the piece were not the purported rebel group but, rather, the government soldiers who came to bully the locals and force them to burn their huts. As such, the rumour resonated more with people's memories of the government's anti-insurgency activities during the war than with the violence perpetrated by the LRM/A (see Atkinson 2010; Branch 2003; 2011; Dolan 2009; Finnström 2009). It was thus not a coincidence that the timing of the rumours coincided with the president's arrival. Rather, having soldiers en masse in Kitgum to "secure the town" for Museveni's visit, as my friend described their presence, reactivated memories of a commonly experienced but silenced past of state violence, and led them to spill over as rumours in the present.

In Kitgum, memories of the past co-mingled with contemporary political events, and the ubiquitous rumours attached to them. The way in which these were discussed, or silenced, in the midst of everyday encounters, reflected how people considered their engagements with the state. For instance, sometime after the death of a vocally critical young NRM MP, Cerinah Nebanda (see Alava 2017b, chapter 7 for more details), I asked two people with whom I was eating whether there had been much talk among their acquaintances about the matter. One of them fell quiet, drank his water and left without saying a word. After a while, the man remaining said, "People are learning not to comment." I sighed and said that things did not sound good, to which he replied, "Yes. These things are happening. And they're going to keep happening. Uganda is moving towards totalitarianism." After a moment's silence, he sang the first lines of the Ugandan national anthem's second verse: 
Oh Uganda! The land of freedom,

our love and labour we give.

And with neighbours all

at our country's call

in peace and friendship we'll live.

In the context of a nation buzzing with rumours about a purported political murder, the irony of the anthem's words could hardly have been more glaring. For many, perhaps particularly in the context of the churches I studied, "Oh Uganda" resounded more as a prayerful lament, rather than as praise. From the perspectives of many of my acquaintances in Kitgum, Uganda was not a land of freedom, nor one of peace and friendship. In addition to the experiences of war, which had cast their shadow on the anthem's glowing portrait of the nation, the image was further tarnished by rumours of deaths like Nebanda's, and by the fears that percolated through everyday lives, none of which lent credence to the notion of Uganda as a land of freedom.

Among the most often-cited of such fears were rumours that the government had spies keeping an eye on anti-government talk and activities in every village, every local council, every workplace and every church (see Alava \& Ssentongo 2016), although people practically never spoke of the stories as rumours, but as facts. These reports intensified at certain times: in 2015, for instance, as the country began to prepare for the 2016 elections, when my friend Orom explained the unlikelihood of Museveni losing in the following way:

You know here, there is a system already in place, everywhere. The state intelligence has officers all over, even in this village here, they are there. I could be a security officer, and you would never know. Or you could be, and none of us would ever know.

"Even here?" I asked, pointing to the serene scenery of houses and fields through which we were walking. "Yes," Orom answered with a serious look on his face. "If you start talking too much against the government, they will report you, and one day the army will come to your door, and you will be taken away. And never be seen again." While recent, documented cases, other than those of prominent politicians like Cerenah Nebanda, were seldom referenced as reasons for such fears by my interlocutors, Cecilie Lanken Verma's longitudinal study spanning a number of years during which she followed the lives of former LRM/A rebels who were retrained and recruited as so-called "NRM cadres", suggests that Orom's fears were not unfounded. Rather, she writes: 
I no longer doubt the very dense presence of spies and government agents scattered over even the vast peripheries of Acholiland - possibly the whole country - in the name of internal and external state security and in the form of a range of different networks and cells to which you can belong as different ranks or categories of informers. That makes for a constant flow of - and a constant suspicion of - information and questions that are considered a matter of or as scrutinizing "politics" and "security".

(Verma 2013, 48)

As noted by Rebecca Tapscott, who has recently conducted research on nonstate security provision in Acholi, there has been speculation as to the actual capacity of such local-level security initiatives and possible spy networks (Tapscott 2017). However, I would argue that from the perspective of Kitgum, and my informants, none of whom as far as I ever learned were themselves involved in such networks, the question of how efficient state security networks actually are, was somewhat irrelevant. Rather, the crucial issue seems to be that in part due to previous experiences of state violence, many people in Acholi believe state security to be extremely and dangerously effective; they believe the state to have, as one of Tapscott's (2017) informants put it, such "long hands", that were they to take up any kind of anti-government activities, the information would quickly reach the ears of the state, with grave repercussions. As Finnström has noted, experiences of violence result in the very real and at times realized "fear of the midnight knock" (2009) by state officials or unidentified assailants presumed supported by the state.

The sense of unsettledness that the rumours provoked in my friends also found its way under my own skin. For instance, when my Internet stopped working on the same day as the soldiers rolled into town prior to Museveni's visit, I became fairly convinced that the malfunction was due to the arrival of powerful tracking devices to spy on internet activity and phone calls in the area. Although I logically surmised that I was probably overreacting, the nagging sense of uncertainty was unsettling, and the fear that the incident retriggered (a fear I had often experienced earlier during the fieldwork) lingered even once the Internet problems were pinpointed as my modem's being outdated. Often, I was fairly sure that much of what I was doing and saying was being reported "somewhere", by someone perhaps even close to me. But the key point to make here is not my own experience, but how my own experience attuned me to understanding that I was not alone with my suspicions, fear and unsettledness - they were sensations I was picking up from, and coming to share with, those around me.

As Meinert has written, in post-war Acholi, "the trick [is] to expect distrust, and then possibly, and carefully, to unfold a sense of trust over time; trust which might, however, later revert to distrust" $(2015,126)$. My own sensations reflected the ambivalences, suspicions, and feelings of not-reallyknowing that colour people's sense of politics in Acholi. This sense is 
foundational for the way in which citizenship is experienced and practiced in this context. The everyday learning processes through which a particular sense of citizenship becomes engrained within Acholi citizens is complemented in moments of extraordinary state presence, what Mbembe calls the carnivals of the postcolonial state. It is to one such carnivalesque moment of citizenship learning that I now turn.

\section{Learning citizenship at the spectacle: Presidential visits at church celebrations}

At the church events which brought Museveni to Kitgum in 2015, the playing field was completely cleared in the president's favour, and no speakers representing the political opposition were allowed onto the podium. The many speeches that preceded the president's address were either utterly apolitical, or sang his praises. Museveni was thus free to craft his speech as he saw fit. The longest segments in Museveni's speeches at the events focused on reprimanding the Acholi. To this end, he employed a gimmick he regularly uses while travelling around the country, that is, he emphasized his key point through the application of a few select words in the local language. At the handover of the Mission in Kitgum, these words were lotuko (players) and loneno (spectators):

For football, you need both... But when you have got lotuko and loneno in the economy, that's a big problem. According to the 2002 Census, it showed that 32 of homesteads were lotuko: they were in the money economy. Sixty-eight percent were loneno. They were just spectating.

At Luwum's commemoration on the following day, Museveni developed the argument further. He mentioned that the previous day someone had complained to him that the problem in Acholi - the reason why they are not lotuko - was that people are poor, but, the president insisted:

You cannot be poor if you have land. The problem isn't poverty, the problem is sleeping. Archbishop Sentamu [a Ugandan cleric currently serving as the Bishop of York, who officiated at the service] can tell you how many people there are in the UK with as many acres of land as you. Poverty is not the problem but sleeping. People must now all be lotuko.

To make sense of the weight of Museveni's claims, they need to be analysed in the context of the political economy of northern Uganda. As mentioned in the contextualising chapter on Uganda, a significant politico-economic divide has cut across northern and southern/central Uganda since colonial times. To this day, almost a decade after the end of war in northern Uganda, the income disparity between the north and the rest of the country remains conspicuous (UNDP 2015, 21). Many of the Acholi lost practically everything 
they owned due to the war. Most notable among their losses, both economically and psychologically, was the loss of their cattle, which were of crucial importance to them: as capital, for tilling the soil, for manure and for forging social cohesion and security through bride price (Alava 2017a). Alongside the loss of cattle, people in the region have undergone years of physical and psychological torment in a war in which Museveni was far from innocent (Branch 2011; Dolan 2009). In consequence of these factors the majority of the Acholi continue to exist on low-technology subsistence agriculture (UBOS 2014). There are many reasons for the scarcity of higher-intensity agriculture and the low level of manufacturing industries in the region, such as unclear land tenure, low-yielding soils, lack of access to external markets (Gollin 2010), and limited access to credit - none of which were mentioned by Museveni in his speech. Arguably, many of these are issues that the government could have influenced to a greater extent than it has; for instance, the most recent agricultural census conducted in Uganda showed that only 6.2 per cent of northern Ugandan farming households had access to credit, in comparison to 14.4 per cent of those in President Museveni's home region of Western Uganda (UBOS 2010).

Museveni concluded his speech by announcing that because so much of the money he had so far sent to the north had been devoured by what he called "clever people", he had decided he would no longer allow civil servants to run development projects in the region (for an analysis of the extensive corruption of "recovery" initiatives in the region, see Golooba-Mutebi \& Hickey 2010). Instead, from now on, special army officers would distribute building materials and farm inputs in what was called "Operation Wealth Creation". Two things stand out in the announcement. First of all, building materials and farm inputs do not go far towards solving the bigger issues of political economy that drive people into subsistence agriculture and maintain high levels of poverty in northern Uganda. Secondly, with this announcement, Museveni narrated himself into the role of the benefactor, placing all the blame for the appropriation of northern Uganda's billions of shillings of aid money on people below him, while simultaneously circumventing claims that the army itself might be corrupt (see Mwenda \& Tangri 2013).

In light of all this it seemed there were good reasons for people to be angered by the president's words, and to express their anger. But no-one did. In contrast to the mass annoyance I witnessed at an event I had attended three years earlier (see Alava 2017b, chapter 6) there were no rebuking sounds of "tst-tst" or shouts of "goppa!" (lies!) directed at Museveni, nor gleeful ululations at the opposition's subtle ridiculing of him - just unbroken silence and thousands of eyes staring either at the ground or in the president's direction. How was it that the audience seemed to accept Museveni's berating without the slightest indication of protest?

To answer this question, we must observe that the President's speeches were not novel, but, rather, drew from a well-rehearsed repertoire of anti-Acholi sentiments. In particular, they resonated with the official discourse by which 
Museveni has internalized the problems of northern Uganda into Acholi throughout the past three decades (Alava 2008). This builds upon racist colonial representations of the Acholi people as essentially warlike and unpredictable and, particularly since the war, as both lazy and shackled by dependency syndrome (Finnström 2008). The speeches were thus a continuation of a dynamic that was evident throughout the northern Ugandan war. State rituals like this one figuratively and literally guide Acholi bodies towards submission. While this submission is at times reversed (see Alava $2017 \mathrm{~b}$ for examples), overall, a submissive habitus has been engrained among many Acholi over the past decades of war and "post-war". Following Mbembe (1992), this submission cannot be seen simply as a case of coercion and lack of opposition; rather,

[i]n the postcolony, an intimate tyranny links the rulers with the ruled, just as ... vulgarity [is] the very condition of state power. If subjection appears more intense than it might be, it is also because the subjects of the commandement have internalized the authoritarian epistemology to the point where they reproduce it themselves in ... daily life.

(Mbembe 1992, 22-23)

Internalization of the authoritarian epistemology takes place within a system of oppression wherein the oppressed "adopt an attitude of 'adhesion' to the oppressor" (Freire 1968/1990, 45 quotation marks in original). As Freire explains, this adhesion "does not necessarily mean that the oppressed are unaware that they are downtrodden, [b]ut their perception of themselves as oppressed is impaired by their submersion in the reality of oppression" (ibid.). Freire's analysis of oppression illuminates the role-play witnessed at the lotuko event I described above, where the president takes on the role of benefactor, and convinces the audience that, due to their inadequacy, his benefaction is what they need (ibid., 49-54).

Self-depreciation is another characteristic of the oppressed, which derives from their internalization of the opinion the oppressors hold of them. So often do they hear that they are good for nothing, know nothing and are incapable of learning anything - that they are sick, lazy, and unproductive - that in the end they become convinced of their own unfitness (Freire 1968/1990, 63).

Freire's description is almost eerily prescient in light of the case I have presented - as if Museveni has read the "Pedagogy of the Oppressed" as an oppressor's guidebook. A profound indication of the humiliation intrinsic to such internalization was provided at the handover of the Catholic Mission in Kitgum, where the chairperson of the District Council (LC5) thanked the president for a cattle-restocking program in which 798 cows had been given to farmers in the district as compensation for those lost to cattle rustlers in previous decades. I quietly asked a friend sitting beside me how many cows his family had lost in the raids, which many people in the area believe were silently condoned if not orchestrated by Museveni to snap the backbone of 
the Acholi. He answered, "Three hundred." Yet the chairperson of the district humbly thanked the president for 798 head of cattle. ${ }^{1}$

In discussions about the relationship between the Acholi and Museveni's state, expressions such as "we have been forgotten" or "we don't exist" are commonly used. The most concise and harsh of such statements that I heard during my fieldwork was made by a well-educated Catholic man in his forties, Komarach, who described the state's attitude to the Acholi thus: "We are like condoms; we're used and thrown away." Komarach's likening of the Acholi to condoms which, as he explained, are used for pleasure but get no part in it themselves, poignantly illustrates the intensity and intimacy with which the relationship with the state is experienced in post-conflict northern Uganda, as well as the sense of humiliation that colours it.

In sum, the lack of expressed annoyance by the crowd listening to Museveni's speech can be read as a result of the submissive habitus tinged with humiliation and shame that many in the region have adopted in relation to the central state. Mbembe holds that the postcolonial bodies which submit to playing the part of the submissive citizen cheering the state do so "precisely in order to better "play' with it and modify it whenever possible" (1992, 22-23). A Mbembeian interpretation of the events - of the large numbers of people who crowded to take part, of the excitement that the events engendered among spectators, and of the laughter sometimes witnessed at similar events in response to opposition leader's inciting and insightful speeches - might suggest carnivalesque enjoyment as a central aspect of public church events and of the performances of statehood seen therein. At the events attended by Museveni in 2015, however, there was none of the playful mockery of the state apparatus that Mbembe describes. Neither did I see such play in the weeks after the clampdown on opposition protests in 2016; nor in the submissive silences into which many retreated as soon as the politics of the state - the army, or state security officials - were raised in discussion. From this it appears that the ludic resources available to the subjects of the postcolonial state are more available for some than they are for others, and at some moments than at others. In contemporary post-war Acholi, these resources are limited by the vulgar and obscene violence of postcolonial performance (Mbembe 1992, 29-30) coupled with the less symbolic and more direct violence of the gun. Indeed, Museveni's transfer of "development initiatives" to the army gave him the perfect reason to deploy the military to rural areas (Vokes \& Wilkins 2016, 592). At times of heightened security in particular, such as in the run-up to elections, there is very little space in Acholi for the kind of laughter Mbembe claims to be subversive. When faced with the inevitability of a gun, that laughter dies.

This threat had practical implications for the rationales by which people judge politics. Even though there seemed to be no immediate threat of violent retaliation were people to stand up and protest, one could not be sure. Opposing the president might turn him even more firmly against the Acholi, hence, rather than rallying in anger, it was better to respond with silence. 


\section{Discussion: How does it feel to be a citizen in Acholi?}

So far, I have argued that in the Acholi region, the violent core of the NRM state inserts itself into the private realm of people's homes, lives and thoughts, so that even in the absence of overt state repression, and in the intervals between the state's public appearances, an under-the-skin sense of the state prompts people into submission. This cautious habitus is the outcome not only of the sense of an external and potentially violent state, but also of often war-related tensions and divisions among the Acholi, which are pressed underfoot and veiled in silence (see Alava 2017b).

Such circumstances have significant impact on the possibilities for ideal, benign citizenship to emerge. In Mbembe's $(1992 ; 2001)$ view, postcolonial citizenship is in part practiced through the employment of ludic resources which citizens can use to challenge and even ridicule the champions of state power. Such ludic resources, however, are constrained in Acholi, where many are persuaded as a result of pragmatic political calculation to adopt a variant of the subjunctive mood (Whyte 2002; 2005) as the cornerstone of their engagements with the Ugandan state. Judging by the analysis of one discouraged former Anglican bishop, Zac Niringiye, the predicament of statecitizen relations in Acholi is not the predicament of northern Uganda alone. He writes:

We must lament the failure of citizenship in Uganda. While the immediate casualty of corrupt and un-accountable leadership is service delivery, the long-term impact is on citizenship. Patronage kills citizenship; citizens are turned into subjects, both the assertion of rights and the exercise of responsibility die. Hence the current state of Ugandan citizenry: fear, apathy and slumber

(Niringiye 2017, 254).

In Niringiye's analysis, the blame is laid principally on the NRM regime; he claims, however, that the results of practiced statehood bleed over time into the realm of the citizen, and that the citizenry can choose how to respond to this bleeding. In Uganda, Niringiye claims, citizens have failed.

[O]ver time Ugandans have surrendered their rights and reneged their responsibilities... Ugandan voters have chosen inducements from the Museveni regime at election time and shied away from harassment that comes with opposition. Citizen organisations have either been killed, such as cooperative societies, or weakened and replaced with patronage networks.

(Niringiye 2017, 255)

Reflecting on Niringiye's words, one can debate whether there is any possibility for citizens or citizens' organizations to respond in anything other than 
subdued ways. What I claim is that the primarily submissive habitus that Acholi citizens have adopted towards the state is adopted on the basis of a pragmatic political calculus. In light of the history of state violence in the region, and the prevalence of on-going state-perpetrated violence, or rumours of it, one can rightly argue that submissive citizenship - "voluntarily" bowing down to the state that has forced you to your knees for decades - is a necessary life-preserving measure.

In this chapter, I have argued that citizenship in northern Uganda is learned in two different but interlinked arenas: first, at spectacular moments of state performance, at which citizens, as members of the audience, are guided towards particular forms of subdued participation; and, secondly, in everyday encounters with representatives of the state, which guide citizens towards particular sets of subdued dispositions. This analysis brings into focus how a sense of citizenship, and thereby practices of citizenship, are learned through embodied experiences: by taking part in public debate; by voting; by greeting a flag and singing the anthem; but also by running away when the army burns your home; by being raped by a soldier; by staying quiet for fear that spies are listening; by having your eyes sting from teargas as the police break up a political rally; by staying quiet and averting your eyes when the president declares that you and your people are good for nothing. The broader lesson to draw from this observation is that, whatever the means one wishes to deploy for fostering growth into citizenship, these means must commence from recognition and analysis of the everyday practices and spectacular events through which existing modes of citizenship have emerged.

\section{Note}

1 During the cattle raids that followed the NRA take-over in 1986, cattle numbers in Acholi decreased from an estimated 123,375 head to between 3,000 and 11,000 (Finnström 2008, 73).

\section{References}

Alava, H. (2008). Interactions of conflict and development intervention in northern Uganda (Master's thesis, University of Helsinki, Helsinki, Finland). Retrieved from https://helda.helsinki.fi/handle/10138/13050

Alava, H. (2017a). Homosexuality, the Holy Family and a failed mass wedding in Catholic northern Uganda. Critical African Studies, 9(1), 32-51.

Alava, H. (2017b). There is confusion: The politics of fear, silence and hope in Catholic and Anglican northern Uganda (Doctoral dissertation, University of Helsinki, Helsinki, Finland).

Alava, H. \& Ssentongo, J. (2016). Religious (de)politicization in Uganda's 2016 elections. Journal of Eastern African Studies, 10(4), 677-692.

Atkinson, R.R. (2010). The roots of ethnicity: The origins of the Acholi of Uganda before 1800 (2nd ed.). Fountain Studies in East African History. Kampala: Oxford. 
Branch, A. (2003). Neither peace nor justice: Political violence and the peasantry in northern Uganda, 1986-1998. African Studies Quarterly, 8(2), 1-31.

Branch, A. (2007). Uganda's civil war and the politics of ICC intervention. Ethics \& International Affairs, 21(2), 179-198.

Branch, A. (2011). Displacing human rights: War and intervention in northern Uganda. New York: Oxford University Press.

Branch, A. (2012). The paradoxes of protection: Aligning against the Lord's Resistance Army. African Security, 5(3-4), 160-178.

Butler, J. (1992). Mbembe's extravagant power. Public Culture, 5(1), 67-74.

Dolan, C. (2009). Social torture: The case of northern Uganda, 1986-2006. New York: Berghahn Books.

Fanon, F. (1967). The wretched of the Earth. Harmondsworth: Penguin Books.

Finnström, S. (2006). Meaningful rebels? Young adult perceptions on the Lord's Resistance Movement/Army in Uganda. In C. Christiansen, M. Utas \& H.E. Vigh (Eds.). Navigating youth, generating adulthood: Social becoming in an African context (pp. 203-227). Uppsala: Nordiska Afrikainstitutet.

Finnström, S. (2008). Living with bad surroundings: War, history, and everyday moments in northern Uganda. Durham, NC: Duke University Press.

Finnström, S. (2009). Fear of the midnight knock: State sovereignty and internal enemies in Uganda. In B. Kapferer \& B.E. Bertelsen (Eds.). Crisis of the state: War and social upheaval (pp. 124-142). Oxford and New York: Berghahn Books.

Finnström, S. (2012). 'KONY 2012', military humanitarianism, and the magic of occult economies. Africa Spectrum, 47(2/3), 127-135.

Freire, P. (1990). Pedagogy of the oppressed. London: Penguin Books. (Original work published 1968).

Gollin, D. (2010). Agriculture, roads, and economic development in Uganda: Edited by Richard Rogerson (NBER Working Paper Series No 15863). The National Bureau of Economic Research. Retrieved from www.nber.org/papers/w15863

Golooba-Mutebi, F. \& Hickey, S. (2010). Governing chronic poverty under inclusive liberalism: The case of the Northern Uganda Social Action Fund. Journal of Development Studies, 46(7), 1216-1239.

Karlström, M. (2003). On the aesthetics and dialogics of power in the postcolony. Africa, 73(1), 57-76.

Kleinman, A. \& Kleinman, J. (1994). How bodies remember: Social memory and bodily experience of criticism, resistance, and delegitimation following China's Cultural Revolution. New Literary History, 35(3), 707-723.

Mbembe, A. (1992). The banality of power and the aesthetics of vulgarity in the postcolony. Public Culture, 4(2), 1-30.

Mbembe, A. (2001). On the postcolony. Berkeley: University of California Press.

Mbembe, A. (2006). On the postcolony: A brief response to critics. African Identities, 4(2), 143-178.

Meinert, L. (2015). Tricky trust: Distrust as a starting point and trust as a social achievement in Uganda. In A.L. Dalsgård, S. Liisberg \& E.O. Pedersen (Eds.). Anthropology and philosophy: Dialogues on trust and hope (pp.113-136). New York: Berghahn Books.

Mwenda, A. (2010). Uganda's politics of foreign aid and violent conflict: The political uses of the LRA rebellion. In T. Allen \& K. Vlassenroot (Eds.). The Lord's Resistance Army: Myth and reality (pp. 45-58). London and New York: Zed Books. 
Mwenda, A.M. \& Tangri, R. (2013). The politics of elite corruption in Africa: Routledge studies on African politics and international relations. New York: Routledge.

Niringiye, D.Z. (2017). Conclusion. In P. Musana, A. Crichton \& C. Howell (Eds.). Ngoma Series Vol. 1: Ugandan churches and the political centre (pp. 242-257). Cambridge: Cambridge Centre for Christianity Worldwide.

Nordstrom, C. (2004). Shadows of war: Violence, power, and international profiteering in the twenty-first century. Berkeley: University of California Press London.

Porter, H. (2016). After rape: Violence, justice and social harmony in Uganda. Cambridge: Cambridge University Press.

Prunier, G. (2004). Rebel movements and proxy warfare: Uganda, Sudan and the Congo (1986-1999). African Affairs, 103(412), 359-383.

Tapscott, R. (2017). The government has long hands: Institutionalized arbitrariness and local security initiatives in Gulu, northern Uganda. Development \& Change, 48(2), $263-285$.

UBOS (2010). Uganda census of agriculture 2008/2009. (Summary Report, Volume 1). Retrieved from www.ubos.org/onlinefiles/uploads/ubos/pdf\%20documents/UCA Summary.pdf

UBOS (2014). Census 2014 report Northern Region: National population and housing census 2014 subcounty report. Retrieved from www.ubos.org/onlinefiles/uploads/ ubos/census_2014_regional_reports/Census_2014_Report_Northern_Region.pdf

UNDP (2015). Uganda human development report 2015: Unlocking the development potential of northern Uganda. Retrieved from http://hdr.undp.org/sites/default/files/ undpug2015_ugandahdr2015.pdf

Verma, C.L. (2013). Guns and tricks: State becoming and political subjectivity in wartorn northern Uganda (Unpublished doctoral dissertation). University of Copenhagen, Denmark.

Vokes, R. \& Wilkins, S. (2016). Party, patronage and coercion in the NRM'S 2016 reelection in Uganda: Imposed or embedded? Journal of Eastern African Studies, 10(4), 581-600.

Whyte, S.R. (2002). Subjectivity and subjunctivity: Hoping for health in Eastern Uganda. In R.P. Werbner (Ed.). Postcolonial subjectivities in Africa (pp. 171-190). London \& New York: Zed Books.

Whyte, S.R. (2005). Uncertain undertakings: Practicing healthcare in the subjunctive mood. In R. Jenkins, H. Jessen \& V. Steffen (Eds.). Managing uncertainty: Ethnographic studies of illness, risk and the struggle for control (pp. 245-264). Copenhagen: Museum Tusculanum Press.

Zeller, W. (2013). Get it while you can: Governance between wars in the UgandaSouth Sudan borderland. In B. Korf \& T. Raeymaekers (Eds.). Violence on the margins: States, conflict, and borderlands (pp. 193-217). Palgrave Series in African Borderlands Studies. New York: Palgrave Macmillan US. 